policemen of a charge of brutality against a black passer-by. Now some sections of the white community are incensed, crying prejudice and political correctness. More deliberation by the jury would have avoided that. As things are, it is a shame that the country that has done most by legislation to promote racial harmony should now be set back by the consequences of a criminal trial.

\section{Tony Blair's highway}

The British Labour Party's new leader has made his first mistake in two years with his superhighway deal.

THE next British government will almost certainly be formed by the British Labour Party, which held its annual conference last week at the seaside town of Brighton in southern England. Prudently, for a government in waiting, it has been circumspect in declining to say what its polices in government will be; if it has views about the proper organization of science, for example, it is not telling. That is one reason for surprise that the party leader, $\mathrm{Mr}$ Tony Blair, should last week have announced that he and his colleagues have made a deal with British Telecom, the privatized communications near-monopoly, under which the company will make no charge for connecting all schools, colleges, public libraries and hospitals in Britain to a broadband data network. A second reason (for being surprised) is that the deal is poorly thought through; a government-in-waiting can only damage itself with such preparation.

Thanks to US Vice-President $\mathrm{Al}$ Gore, access to the Internet, especially for the very young, is fast being spoken of as if it were one of the basic human rights listed by the United Nations. The educational value of such arrangements may well be as great as Gore (and now Blair) says, although the point has not been demonstrated with the clarity that would normally be required to justify the physical cost involved. Unsurprisingly, last week's conference was also loud with demands that money should be found for this or that improvement of the conventional educational system, many of which made excellent sense. Is it self-evident that access to the superhighway takes precedence over all of them - the need for more and better teachers, especially in science subjects, for example? Blair's supporters will no doubt argue that this cavil is beside the point; has not British Telecom promised to make the connections free of charge? That is a question to put to those who believe there is such a thing as a free lunch.

Objections to Blair's deal fall under two heads, commercial and constitutional. The commercial aspects of the deal do not imply unadulterated altruism on the part of British Telecom. It emerged last week, but less quickly than it might have done, that in return for connecting public institutions to the Internet and beyond, British Telecom will win the right to use whatever broadband network it installs to distribute television and other 'multimedia' signals to all who are connected to the network, either as a common-carrier or as a provider in its own right.
The company was specifically denied that right when it was privatized in 1982. Instead, the then government (whose successors are still in office) decreed that the task of 'cabling Britain' would be entrusted to a patchwork of cable television companies, that they would be free to offer telephone services to their subscribers and that British Telecom would be kept out of the supply of multimedia services at least until 2002. Although British Telecom is a partner in several of the cable companies (as are 'baby Bells' such as Nynex from the United States), British Telecom has been complaining throughout this period that it cannot be expected to install a countrywide modern communications network if it cannot get its money back by helping to meet the only established multimedia market, that for films and other video-spectacles such as prize-fights. Blair's deal will give British Telecom the prize it has been seeking all these years.

That is unwise, to say the least. Not least, it prejudices the decisions that will have to be made in 2002 or preferably sooner (see Nature 372, 303-304; 1994). The privatization of 1982 has succeeded in one respect: British Telecom has become much more efficient, so much so that it is well on the way to seeing off its government-appointed competitor in the field, Mercury Communications. Until AT\&T won the right, earlier this year, to set up in Britain, British Telecom seemed well on the way to the restoration in private hands of the public monopoly it previously enjoyed. It is natural that it should now seek a friendly deal with the next government, one that, by offering something apparently for nothing, will make it difficult for that government to be beastly in 2002. To be fair to British Telecom, of course, the investment of $£ 10$ billion or so in a new broadband network will not be risk-free, but it is a safer gamble than some of the options for 2002. Breaking up British Telecom into smaller pieces, perhaps around the cable companies (which have already invested in broadband cable) is one of them. If Blair's deal has foreclosed that option, he will regret it.

The constitutional issue is something else. "New Labour", which is what Blair and his colleagues call their party, may be on the threshold of power, but it has plainly not yet appreciated how much power it will have if it is voted in. In the absence of a formal constitution, its power in the telecommunications field will be virtually absolute. If it were decided that the free connection of all public institutions to a broadband network is essential to Britain's future, a new government could simply make that a condition of the renewal of the licence under which British Telecom operates (and which is not part of statute law, but a commercially binding undertaking), obliging it to connect public institutions to its network free of charge. Or it could offer a similar deal to AT\&T, or to the recently formed partnership between the German and French telecommunications outfits. Alternatively, it could impose a special tax on the monopoly (like the tax proposed for the privatized water utilities) and use that to pay for the connections it believes it needs. Instead, it has chosen to tie its hands in advance. That is thoughtless, and will seem naive. 